УДК 378.14 (477)

DOI: $10.35619 /$ iiu.v1i10.190

\author{
Руденко Володимир \\ доктор педагогічних наук, професор, \\ професор кафедри педагогіки і психології \\ (дошкільної та корекційної) \\ імені проф. Т.І.Поніманської \\ Рівненського державного гуманітарного університету, \\ м.Рівне. Україна \\ ORCID: 0000-0001-5986-264X \\ e-mail:VRudenko2004@gmail.com
}

\title{
МОДЕЛЮВАННЯ КУЛЬТУРОЛОГІЧНОЇ СПРЯМОВАНОСТІ ЗМІСТУ ВИЩОЇ ОСВІТИ
}

\begin{abstract}
Анотація. Моделювання культурологічної спрямованості змісту вищої освіти закладене на підставах ізоморфної тотожності освіти і культури. Основна ідея полягає в наповненні змісту вищої освіти когнітивними, ціннісними та регулятивними формами смислового розуміння культури. Зміст навчання $\mathrm{i}$ виховання диференційовано представлено у контексті культури і цивілізації. Цільовий компонент вищої освіти вибудовується в рамках культурологічної парадигми гуманістичного типу (парадигми людини культури), що визначає необхідні і достатні умови для становлення цілісної системи професійно-особистісних якостей випускника вищої школи. Модель презентує єдність духовно-моральних і професійно-технологічних компонентів підготовки. Це відображає об'єктивну потребу людини, суспільства і держави у високому рівні розвитку професіоналізму, компетентності та особистісних якостей майбутніх фахівців. Модель змісту вищої освіти відображає основні дидактичні ознаки і характеристики будови та функціонування сучасної гуманітарної культурно-освітньої системи. Сукупність концептуальних засад розглядається на основі діалектики єдності культурології та антропології. На теоретичному та нормативному рівнях моделювання закладена можливість подання змісту вищої освіти за допомогою категорій «значення» і «сенс» як засобу перетворення на їх основі духовних, соціальних і технологічних компонентів культури у цілісну «предметну реальність». Освітній процес моделюється як своєрідний культурний акт (подія), що спирається на ціннісну ієрархію, а також механізми засвоєння змісту шляхом переведення суб'єктами значень на рівень особистісних когнітивних, ціннісних та регулятивних сенсів. Особистісні сенси є головними складовими в структурі цілісної свідомості особистості й одночасно - універсальними структурними елементами культури.
\end{abstract}

Ключові слова: культура, цивілізація, модель, зміст, цінність, значення, сенс.

Постановка проблеми. Вивчення особливостей сучасного стану і перспектив розвитку освіти і педагогіки вищої школи в умовах переходу спільноти від техногенної до антропогенної цивілізації показало, що світові інтеграційні процеси, домінування гуманістичної парадигми у педагогічній теорії і практиці, а також нові соціокультурні реалії диктують необхідність інноваційних підходів до проєктування оптимальних систем освіти. У XXI столітті вузькопрофесійна підготовка молоді вже не відповідає вимогам часу. Вища освіта перестає бути тільки професійною, вона стає елементом загальної культури особистості. Моделюючи цілісний образ випускника закладу вищої освіти, учені єдині в тому, що фахівець повинен бути перш за все людиною культури, тобто вільною, гуманною, духовною особистістю, орієнтованою на цінності світової і національної культури, здатною до творчої самореалізації в світі культурних 
цінностей, до етичної саморегуляції і адаптації в соціокультурному середовищі (Бондаревська, 1999). Все це викликає необхідність проєктування оптимальних систем освіти, які повинні «максимально повно відповідати сучасному типу культури, даючи відповідь на актуальні питання сучасної цивілізації» (Запесоцький, 2002).

Аналіз останніх досліджень 3 проблеми. Проблема відповідності змісту освіти потребам розвитку цивілізаційних і культурних процесів $є$ проблемою «вічною і перманентною». Вона періодично виникає не тільки у вітчизняній, але й у світовій освітній системі. Криза, що знаходиться всередині самої освіти в її методологічних підставах, обумовлена переходом від знаннєво-просвітницької парадигми до культуротворчої, від «людини освіченої» до «людини культури» (Бондаревська, 1999), від «соціального замовлення, що абстрактно розуміється» до «потреб і запитів людини, що розвивається» (Сєриков, 1999) і пов'язана 3 «дефіцитом культури в освіті» (Зінченко, 2002), з «технократичним перевантаженням освіти» (Данильчук, 1998), 3 «трансляцією знання у відчуженій, безособовій формі, яка себе вичерпала» (Сенько, 2000), з «насиченням змісту знаннями за відсутності сенсів» (Леонтьєв, 1975).

Як відомо, зміст освіти є віддзеркаленням культури певної епохи. У той же час, існуюча система вищої освіти багато в чому побудована на культурних домінантах минулого - раціональному погляді на світ, інтелектуалізмі, утилітарності. Цивілізаційна однобічність виразно виявляється в змісті освіти, де знання про цілісний світ людини і досвід цілісної діяльності відсунуті на другорядний план у порівнянні 3 науковою монокультурою. Отже, пошуки систем освіти, які б адекватно відповідали сучасному типу культури і новому етапу розвитку цивілізації, складають одну 3 актуальних проблем сучасної педагогіки, вирішення якої можливе шляхом звернення освіти до своїх фундаментальних витоків - розгляду іiі як частини культури, культуровідповідної системи, культуротворчого процесу.

Мета статті. Розробити прогностичні моделі змісту вищої освіти в контексті культури на різних рівнях його представлення: концептуальному, компетентносному, навчального предмета, навчального матеріалу.

Виклад основного матеріалу дослідження. Дослідження в сфері освіти і педагогіки вищої школи (І. Бех, І. Зязюн, А. Валицкая, М. Розов та інші) дають підстави сформулювати вихідну гіпотезу про те, що моделювання культурологічної спрямованості професійної освіти може виступити теоретичним підгрунтям концепції виховання цілісної особистості - «людини культури», яка характеризується єдністю професійних та особистісних якостей (Руденко, 2003).

Гносеологічна категорія «моделювання» характеризує один зі шляхів пізнання, який дає можливість перенесення результатів, отриманих під час побудови і вивчення моделей, на оригінал. Моделювання вищої освіти здійснювалося за логікою педагогічного дослідження, яка «є послідовністю переходів від емпіричного опису педагогічної дійсності до їі відображення в теоретичних моделях і нормативній формі» (Краєвський, 2001). Враховуючи багатомірність взаємозв'язку освіти і культури, прогностична модель може бути представлена ієрархічною системою окремих моделей на рівнях загальних теоретичних уявлень (концептуальної ідеї); структури основних компонентів змісту (ключових компетенцій); навчального матеріалу; процесу навчання.

На рівні концептуальної ідеї модель змісту вищої освіти представлена схемою гуманітарної культурно-освітньої системи (рис. 1). 


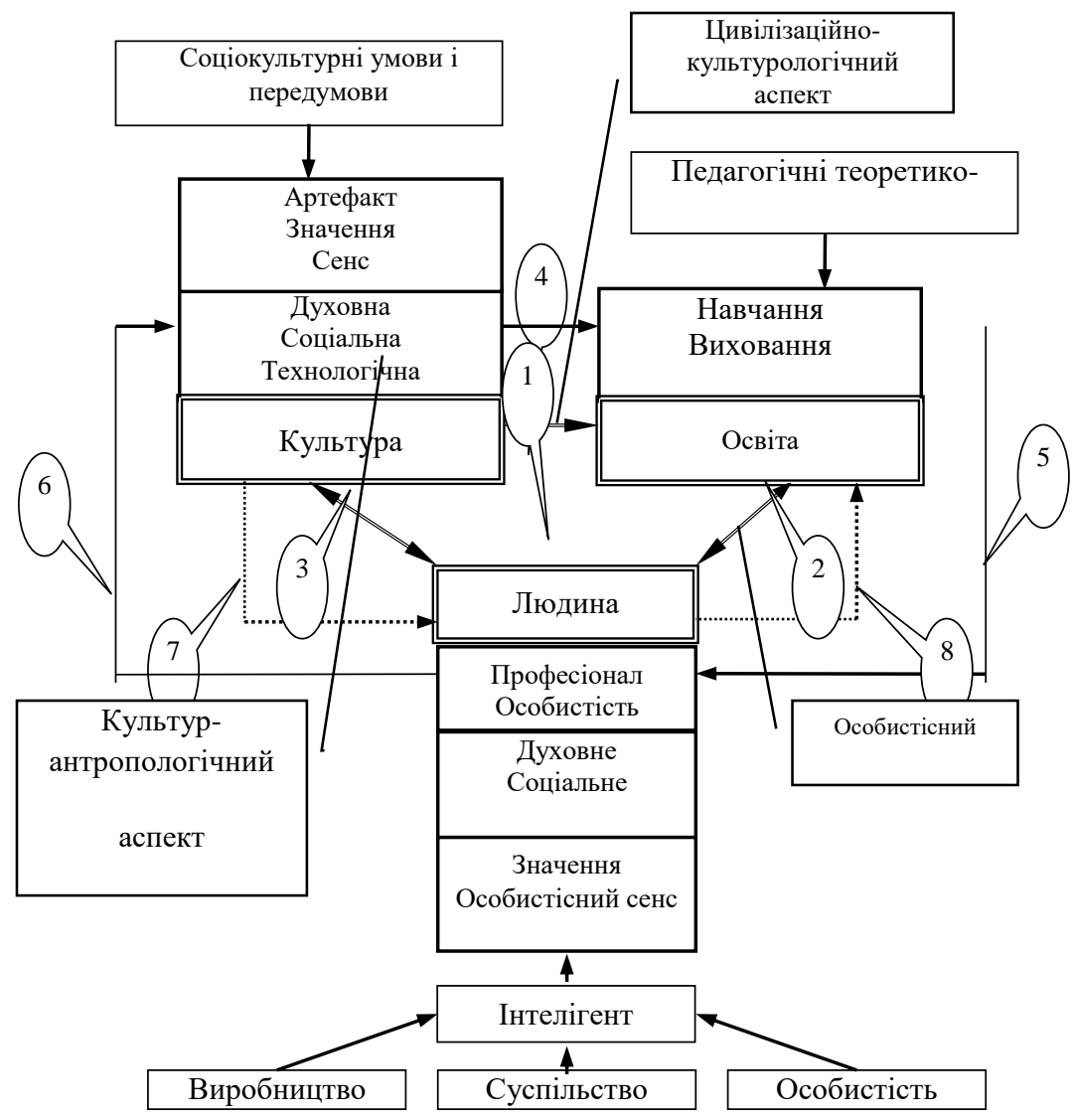

Рис. 1. Модель змісту вищої освіти на рівні концептуальної ідеї.

Системоутворюючими елементами моделі (iї підсистемами) $є$ : «Культура», «Oсвіта», «Людина», між якими існують причинно-наслідкові, змістовні і процесуальні взаємозв'язки (винесення 1, 2, 3). Кожній підсистемі відповідає провідне (головне) протиріччя і функція: «Людина» (професіонал - особистість) - мета, «Культура» (цивілізація - культура) - вектор розвитку, «Освіта» (зовнішня інституційна форма - внутрішній суб'єктний процес становлення) - цінність, результат i засіб. Головними підставами, що визначають характер культурологічної спрямованості змісту вищої освіти, $є$ :

- Соціокультурні умови і передумови (з боку культури): перехід від техногенної до антропогенної цивілізації, ринковий характер економічної основи суспільства, демократизація політичної, соціальної і духовної сфер життя, відмова від монокультури і моноідеології, перехід до полікультурної ситуації; варіативність системи загальної і професійної освіти.

- Педагогічні теоретико-методологічні підстави (з боку освіти): гуманістична педагогічна доктрина, особистісно-орієнтовані концепції освіти, культурологічний професійно-особистісний підхід, компетентнісний підхід, цивілізаційнокультурологічна парадигма. 
Мета вищої освіти як досягнення системи професійних і особистісних якостей та властивостей людини виражена через інтеграційне поняття «інтелігент, інтелігентний - розумово розвинутий; освічений, культурний» (Яременко та Сліпушко, 2006 , с. 794), що відображає сучасні уявлення про культурно-виховний і освітній ідеал (зразок) випускника вищої школи. Мета враховує головні пріоритетні напрями розвитку основних зацікавлених суб'єктів: виробництва (держави) - випереджаючий характер, суспільства - демократизація, особистості - гуманізація. Культурологічна орієнтованість освіти створює умови для розвитку якостей особистості студента, які потрібні і йому, і суспільству, і державі (саме у такій послідовності). Вона забезпечує надалі випускникові можливість активної і повноцінної участі в професійному (виробничому), суспільному і культурному житті.

Циклічність функціонування системи «Культура $\rightarrow$ Освіта $\rightarrow$ Людина $\rightarrow$ Культура» виявляється в тому, що високий рівень культури, як в цілому, так і кожного iii окремого компонента (духовного, соціального і технологічного), вимагає (винесення 4) і вищого рівня освіти, адекватності ії змісту тим самим компонентам. Через освіту (зокрема й через іiі вищий ступінь) здійснюється цілеспрямована реалізація найважливіших соціокультурних i особистісних функцій: соціалізація людини, входження ії в світ культури, особистісне індивідуальне самовизначення (винесення 5). Своєю чергою, фізично здорова духовна людина - необхідна умова подальшої трансляції матеріальних і духовних цінностей у вигляді нових культурних форм i зразків творчої людської діяльності (винесення 6). Як бачимо, коло замикається.

Цивілізаційно-культурологічний підхід дозволяє диференціювати явища культурно-історичного процесу у вигляді потенційних джерел і чинників змісту вищої освіти. Це відкриває можливість обгрунтовано ідентифікувати цивілізаційні і культурологічні компоненти освіти, чіткіше встановити їхні критерії (див. табл.1), адекватно оцінювати наслідки реалізації закладених у них можливостей.

\begin{tabular}{|c|c|c|c|}
\hline \multirow{2}{*}{$\begin{array}{l}\text { № } \\
\text { 규 }\end{array}$} & \multirow{2}{*}{$\begin{array}{c}\text { Критерії } \\
\text { концептуалізації } \\
\text { освіти }\end{array}$} & \multicolumn{2}{|c|}{ Домінуючі значення критеріїв: } \\
\hline & & цивілізаційні & Культурологічні \\
\hline 1 & $\begin{array}{c}\text { Відношення до } \\
\text { особистості }\end{array}$ & Засіб & Мета \\
\hline 2 & Модус особистості & «Мати» & «Бути» \\
\hline 3 & Методологічна база & $\begin{array}{l}\text { Монокультурна } \\
\text { матеріалістична }\end{array}$ & $\begin{array}{c}\text { Методологічний } \\
\text { плюралізм }\end{array}$ \\
\hline 4 & Мета освіти & Людина освічена & Людина культури \\
\hline 5 & $\begin{array}{c}\text { Домінуюча освітня } \\
\text { парадигма }\end{array}$ & Технократична & Гуманістична \\
\hline 6 & $\begin{array}{c}\text { Освітні концепції і } \\
\text { технології } \\
\end{array}$ & $\begin{array}{l}\text { Офіційно визнані } \\
\text { соціо-орієнтовані }\end{array}$ & $\begin{array}{c}\text { Варіативні особистісно- } \\
\text { орієнтовані }\end{array}$ \\
\hline 7 & Компоненти змісту & $\begin{array}{c}\text { Технологічна, } \\
\text { соціальна }\end{array}$ & $\begin{array}{c}\text { Технологічна, соціальна, } \\
\text { духовна }\end{array}$ \\
\hline 8 & Рівень пізнання & Сутність, сенс & Особистісний сенс \\
\hline 9 & Основа пізнання & Мислення & Свідомість \\
\hline 10 & Тип мислення & Природничонауковий & $\begin{array}{c}\text { Природничонауковий i } \\
\text { гуманітарний }\end{array}$ \\
\hline 11 & $\begin{array}{l}\text { Відносини учасників } \\
\text { освітнього процесу }\end{array}$ & Суб'єкт-об'єктий & Суб’єкт-суб’ єктний \\
\hline 12 & $\begin{array}{c}\text { Джерело управління i } \\
\text { розвитку освіти }\end{array}$ & $\begin{array}{l}\text { Зовнішня керована } \\
\text { дія }\end{array}$ & Саморозвиток \\
\hline 13 & $\begin{array}{c}\text { Системна організації } \\
\text { освіти }\end{array}$ & Відкрита система & $\begin{array}{c}\text { Самоорганізовувана } \\
\text { відкрита система }\end{array}$ \\
\hline 14 & $\begin{array}{c}\text { Характер учбової } \\
\text { діяльності }\end{array}$ & $\begin{array}{c}\text { Репродуктивний, } \\
\text { творчий }\end{array}$ & Креативний \\
\hline
\end{tabular}




\begin{tabular}{|c|c|c|c|}
\hline 15 & Показники освіти & Кількісні & Якісні \\
\hline 16 & $\begin{array}{c}\text { Актуальний рівень } \\
\text { потреб }\end{array}$ & $\begin{array}{c}\text { Фізіологічний, } \\
\text { безпеки, соціальних } \\
\text { зв'язків, досягнення }\end{array}$ & $\begin{array}{c}\text { Визнання, схвалення, } \\
\text { само актуалізації }\end{array}$ \\
\hline
\end{tabular}

Цивілізаційно-культурологічний підхід показує перспективи оновлення змісту вищої освіти за такими стратегічними напрямами :

Цивілізаційний напрям: приведення змісту у відповідність із соціальними і демократичними змінами в суспільстві (ринкова економіка, демократія, деідеологізація, деполітизація та ін.); приведення змісту у відповідність 3 рівнем науково-технічного прогресу (математизація, комп'ютеризація, інформатизація та ін.); перенесення змісту 3 емпіричної основи на концептуальну (фундаменталізація, методологізація, використання провідних ідей, теорій, понять, високого рівня узагальнень тощо); організація змісту на структурно-модульній основі, використання методів стандартизації якості в освіті.

Культурологічний напрям: переклад змісту з рівня значень на рівень особистісних сенсів, ціннісних орієнтацій; перехід організації змісту на проєктний принцип, що припускає добудовування і конструювання його студентами, як необхідна складова педагогічної самоорганізації; варіативність змісту освіти як розширення можливостей компетентного вибору студентом свого життєвого шляху і саморозвитку; перерозподіл теоретичного i практичного, гуманітарного i природничо-наукового знання у бік посилення гуманістичної спрямованості.

Моделювання культурологічної спрямованості на piвні змісту полягає у визначенні набору ключових компетенцій у вигляді універсальних знань, умінь, навичок, які можуть бути використані в різних видах діяльності для вирішення виробничих i життєво значущих проблем. Структура компетенцій включає когнітивний, діяльнісний і особистісний компоненти. Розгортання змісту освіти у межах ключових компетенцій трансформує діяльність студентів у переході від знеособлених «значень» до особистісних «сенсів» на основі ціннісного відношення до знань. Культурологічна спрямованість змісту припускає перехід від одновимірних уявлень до багатовимірної предметної рельності. У результаті в зміст включається не тільки ії об'єктна сторона (об'єкти вивчення і дії з ними), але й суб'єктна позиція студента, його мотиваційна сфера, ціннісно-смислове відношення до предмета, особистий (зокрема життєвий) досвід, активність, особові структури свідомості.

Професійно-особистісні якості - це здатності студента усвідомлювати в реальних i/або ідеальних об'єктах властивості в поняттях «значення», «сенс», «відношення», «цінність», це уміння виходити в ширший контекст предметної області, розуміти співвідношення мотиву і мети діяльності.

Моделювання культурологічної спрямованості змісту на рівні навчального курсу залежить від предметної області навчальної дисципліни (гуманітарних, технічних, математичних тощо). За змістом вони можуть бути віднесені або до однієї певної сфери культури (духовної, соціальної, технологічної), або подаватися у вигляді інтегрованих курсів (наприклад, «Філософія освіти», «Історія фізики» та ін.). Проте аналіз структури і змісту цих курсів показує, що включений у них матеріал найчастіше збудований у традиційній природничо-науковій парадигмі, і передбачає засвоєння цього матеріалу лише на рівні значень і монокультурних сенсів. Тому особливості моделювання культурологічної спрямованості принципово не залежать від змісту конкретної дисципліни. Предметна область змісту навчальної дисципліни, за якою вона може бути віднесена до тієї або іншої сфери культури, задає лише початкову ситуацію, відправну позицію для розгортання освітнього процесу в руслі культурологічної спрямованості.

Прогностичну модель культурологічної спрямованості змісту вищої освіти на рівні структури його основних елементів представлено на рис. 2. 


\section{Культура Освіта}

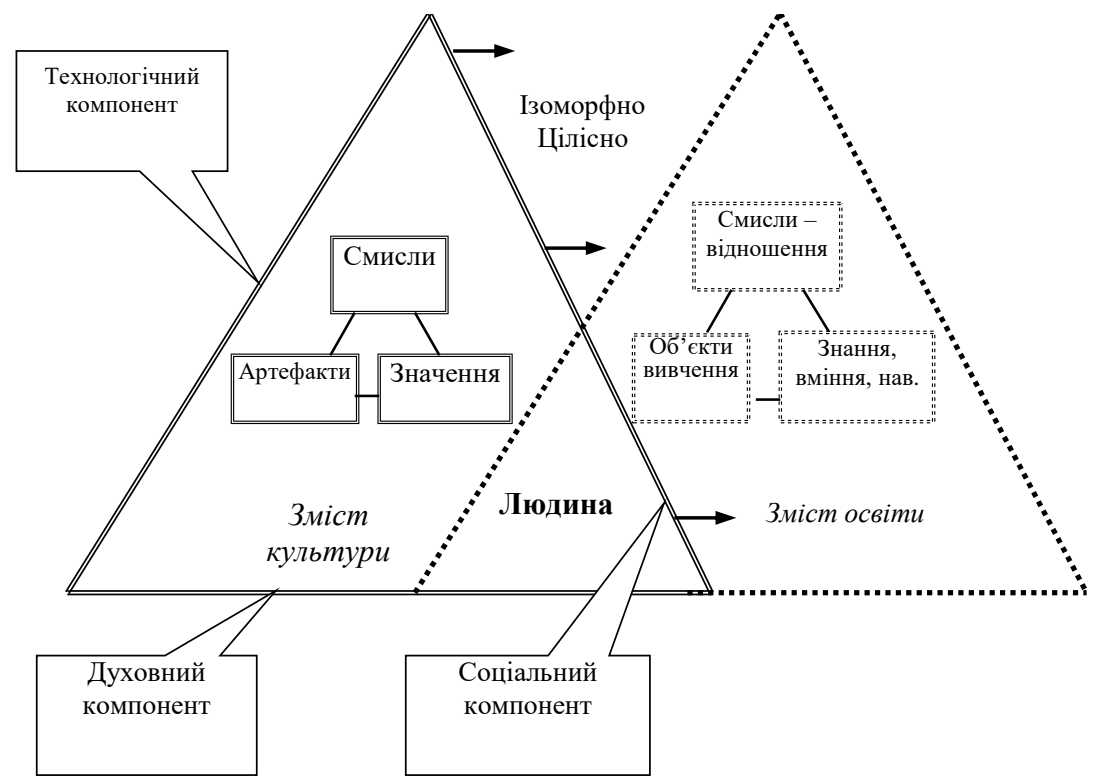

Рис. 2. Модель змісту вищої освіти на рівні структури основних елементів.

Освітня модель ізоморфно відображає системно-структурну будову культури, що складається 3 духовного, соціального і технологічного компонентів у трьох основних аспектах (артефактів, сенсів і знаків). Моделювання змісту освіти на рівні уявлень навчального матеріалу засноване на поетапній реконструкції змісту в категорії «предметна реальність»:

- I етап формування змісту (етап монопредметних зв'язків значень) включає конкретизацію цілей (завдань) освіти, відбір і уточнення реальних i/aбо ідеальних об'єктів вивчення, визначення елементів змісту на рівні значень (знань), а також елементів змісту на рівні відносин як об'єктивних монокультурних зв'язків усередині предмета і зв'язків міжпредметних;

- II етап включає проєктування суб'єктами освітнього процесу області «предметної реальності», яка характеризується появою нового елемента в об'єкті, що вивчається, але приналежний до суміжної культурної області, наприклад, соціальної (або духовної);

- III етап - це проєктування змісту на рівні поліпредметних зв'язків, що приводить до утворення якісно нового смислового елемента змісту, об'єднуючого різні властивості об'єкта, які відносяться до різних компонентів культури, наприклад, технологічної і духовної. Це відношення можна трактувати як об'єктивний культурний сенс.

Моделі культурно-освітніх форм розглядають освітній процес як культурноосвітню подію (культурний акт). На рівні освітнього процесу цілісність змісту освіти як результат його культурологічної спрямованості виявляється в способах його засвоєння, які передбачають розкриття смислового аспекту знань через систему особових структур свідомості, тобто перетворення значень 3 об'єктивних цінностей в особистісно значущі для кожного студента. Процес когнітивно-ціннісно-регулятивного сенсоутворення з точки зору культурологічного підходу становить єдність засвоєння 
елементів духовного, соціального та технологічного компонентів культури і може мати два основні варіанти розвитку, доповнюючих один одного:

- зміст курсу предмета цілком належить до однієї області культури (значення і сенси відносяться тільки до одного компонента культури);

- значення і сенси охоплюють суміжні області культури і приєднуються до тієї сфери, до якої можна безпосередньо віднести зміст курсу предмета (значення і сенси можуть відноситися до декількох компонентів культури).

Перший варіант відповідає традиційній навчально-пізнавальній діяльності в межах монопредметного змісту освіти. У другому - відбувається підвищення смислового потенціалу культурно-освітньої форми, що розуміється як універсальний культурний акт. Діяльність суб'єктів освітнього процесу з переведення сенсів на індивідуальноособовий рівень засвоєння включає наступні дії: сумісне уточнення і довизначення суб'єктами освітнього процесу цілей навчання, визначення й актуалізація системи суб'єктних цінностей, реконструкція власної суб'єктної позиції щодо значень, залучення аксіологічних способів мислення, а також й інші дії миследіяльності.

Динаміка відношення «суб'єктивного сенсу i значення» та закономірності породження особистих сенсів такі, що особистісний сенс на відміну від засвоюваного власне значення, «має відношення не до всього відображеного змісту, а лише до того, на яке спрямована діяльність суб'єкта» (Леонтьєв, 1975). Тому породження особистісного сенсу не може здійснюватися в рамках інших (можливо, доволі корисних з практичної, пізнавально-світоглядної точок зору) додаткових тем і розділів, покликаних заповнити недолік, головним чином, знань (значень) філософського і методологічного характеру. Визначення системи умов породження особистісних сенсів у молоді в процесі навчання в загальному плані витікає 3 того факту, що «будова свідомості людини закономірно пов'язана з будовою ії діяльності» (Леонтьєв, 1975). Отже, розвиток свідомості у напрямі наповнення іiі сенсами можливий лише в умовах осмисленої, смислопороджуючої, смислотворчої діяльності у сфері конкретного засвоюваного змісту і з приводу цього змісту.

Моделювання культурологічної спрямованості змісту на рівні освітнього процесу виражається в зміні відношення мети і мотиву навчальної діяльності студента. Для суб'єкта досягнення ним конкретних цілей, оволодіння засобами і операціями дії є способом ствердження його життя, задоволення його матеріальних і духовних потреб, опредметнених у мотивах його діяльності. Функція мотивів полягає в «оцінці» життєвого значення об'єктивних обставин для суб'єкта і його дій у цих обставинах, при цьому особистісний сенс може прямо і не співпадати з об'єктивним їх значенням, як воно розуміється. На відміну від значень, які пов'язані у свідомості суб'єкта 3 реальністю об'єктивного світу, особистісний сенс пов'язує ці значення з реальністю життя самого суб'єкта. Отже, на рівні освітнього процесу культурологічна спрямованість означає розкриття в змісті всієї суб'єктної реальності (цінностей, мотивів, буденного досвіду, ненаукових знань, міфологічних уявлень тощо) - всього, що наявне в самому житті суб'єкта.

Висновки і перспективи подальших розвідок. Моделювання культурологічної спрямованості змісту вищої освіти закладене на підставах ізоморфної тотожності освіти і культури. Основна ідея полягає в наповненні змісту вищої освіти когнітивними, ціннісними та регулятивними формами смислового розуміння культури в процесі професійної підготовки. Зміст навчання і виховання диференційовано представлено в контексті культури і цивілізації. Цільовий компонент вищої освіти вибудовується в межах культурологічної парадигми гуманістичного типу (парадигми людини культури), що визначає необхідні і достатні умови для становлення цілісної системи професійно-особистісних якостей майбутнього фахівця. Модель фахівця презентує єдність духовно-моральних i професійно-технологічних компонентів підготовки. Це відображає об'єктивну потребу людини, суспільства і держави у 
високому рівні розвитку професіоналізму, компетентності та особистісних якостей майбутніх фахівців.

Модель змісту вищої освіти відображає основні дидактичні ознаки i характеристики будови та функціонування сучасної гуманітарної культурно-освітньої системи. Сукупність концептуальних засад вибудувана на основі діалектики єдності культурології та антропології, розкритих на філософському, загальнонауковому і психолого-педагогічному рівнях уявлення. На нормативному рівні моделювання закладена можливість подання змісту вищої освіти за допомогою категорій «значення» i «сенс» як засобу інтеграції на їх основі духовних, соціальних і технологічних компонентів культури в цілісну «предметну реальність». Освітній процес моделюється як своєрідний культурний акт (подія), що спирається на ціннісну ієрархію, а також механізми засвоєння змісту у вигляді значень шляхом переведення їх суб'єктами на рівень особистісних сенсів (когнітивних, ціннісних, регулятивних). Останні $\epsilon$ головними складовими в структурі цілісної свідомості особистості і одночасно універсальними структурними елементами культури.

\section{СПИСОК ВИКОРИСТАНИХ ДЖЕРЕЛ}

Бондаревская, Е., Кульневич, С. (1999). Педагогика: Личность в гуманистических теориях и системах воспитания. Москва - Ростов н/Д. 560 с.

Запесоцкий, А. (2002). Образование: философия, культурология, политика. Москва: Наука. 456 с.

Сериков, В. (1999). Образование и личность. Москва: Перемена. 376 с.

Зинченко, В.(2002). Психологические основы педагогики. Москва: Гардарики. 431c.

Данильчук, В. (1998). Гуманитарная парадигма в проектировании педагогического образования. Развитие личности в образовательных системах Южно-российского региона. Ростов н/Д. С. 85.

Сенько, Ю. (2000). Гуманитарные основы педагогического образования. Москва: Издательский центр «Академия». 240 с.

Леонтьев, А. (1975). Деятельность, сознание, личность. Москва: Политиздат. 304 c.

Бех, І. (2003). Особистісно орієнтований підхід: науково-практичні засади. Київ: Либідь. 344 с.

Зязюн, І., Крамущенко, Л. та Кривонос, І. (1997). Педагогічна майстерність. Київ: Вища школа. 349 с.

Валицкая, А. (1997).Философские основания современной парадигмы образования. Педагогика. № 3. С.15-20.

Розов, Н. (1992). Культура, ценности и образование. Москва. 155 с.

Яременко, В. та Сліпушко, О. (2006). Новий тлумачний словник украӥнської мови. Київ: Аконіт. С. 794.

Руденко, В. (2003). Культурологический профессионально-личностный подход к высшему образованию. Науковий вісник ПДПУ ім. К.Д. Ушинського. Випуск 1-2.Одеса: ПДПУ ім. К. Д. Ушинського. С. 33-44.

Краевский, В. (2001). Методология педагогики. Чебоксары. 244 с.

\section{REFERENCES}

Bondarevskaya, E., Kulnevich, S. (1999). Pedagogika: Lichnost v gumanisticheskikh teoriyakh $i$ sistemakh vospitaniya [Pedagogy: Personality in Humanistic Theories and Education Systems]. Moskva - Rostov n/D. 560 s. (in Russian)

Zapesotskiy, A. (2002). Obrazovanie: filosofiya, kulturologiya, politika [Education: Philosophy, Cultural Studies, Politics]. Moskva: Nauka. 456 s. (in Russian)

Serikov, V. (1999). Obrazovanie $i$ lichnost [Education and Personality]. Moskva: Peremena. $376 \mathrm{~s}$.

Zinchenko, V.(2002). Psihologicheskiye osnovy pedagogiki [The Psychological Foundations of Pedagogy]. Moskva: Gardariki. 431 s. (in Russian) 
Danilchuk, V. (1998). Gumanitarnaya paradigma v proektirovaniyi pedagogicheskogo obrazovaniya. [Humanitarian Paradigm in the Design of Teacher Education] Razvitie lichnosti v obrazovatelnyih sistemah Yuzhno-rossiyskogo regiona. Rostov n/D. S.85. (in Russian)

Senko, Yu. (2000). Gumanitarnyye osnovy pedagogicheskogo obrazovaniya [Humanitarian Foundations of Teacher Education]. Moskva: Izdatelskiy tsentr "Akademiya". 240 s. (in Russian)

Leontev, A. (1975). Deyatelnost, soznanie, lichnost [Activity, Consciousness, Personality]. Moskva: Politizdat. 304 s. (in Russian)

Bekh, I. (2003). Osobystisno oriientovanyi pidkhid: naukovo-praktychni zasady [A Personally Oriented Approach: Scientific and Practical Basics]. Kyiv: Lybid. 344 s. (in Ukrainian)

Ziaziun, I., Kramushchenko, L. \& Kryvonos, I. (1997). Pedahohichna maisternist [Pedagogical Skills]. Kyiv: Vyshcha shkola. 349 s. (in Ukrainian)

Valitskaya, A. (1997). Filosofskiye osnovaniya sovremennoy paradigmy obrazovaniya [The Philosophical Foundations of the Modern Paradigm of Education]. Pedagogika. No 3. s.15-20. (in Russian)

Rozov, N. (1992). Kultura, tsennosti i obrazovanie [Culture, Values and Education]. Moskva. 155 s. (in Russian)

Yaremenko, V., Slipushko, O. (2006). Novyi tlumachnyi slovnyk ukrainskoi movy [New Interpretative Dictionary of the Ukrainian Language]. Kyiv: Akonit. s. 794. (in Ukrainian)

Rudenko, V. (2003). Kulturologicheskiy professionalno-lichnostnyiy podhod $\mathrm{k}$ vyisshemu obrazovaniyu [Culturological Professional and Personal Approach to Higher Education]. Naukoviy visnik PDPU im. K.D. Ushynskoho. Vypusk 1-2.Odesa: PDPU im. K.D. Ushynskoho. S. 33-44. (in Russian)

Kraevskiy, V. (2001). Metodologiya pedagogiki [Pedagogical Methodology]. Cheboksary. 244 s. (in Russian)

\title{
CULTURAL TRENDS MODELING OF HIGHER EDUCATION CONTENT
}

\author{
RudenkoVolodymyr \\ Doctor of Sciences (in Pedagogy), \\ Professor, Professor at the Department of Pedagogy \\ and Psychology (Preschool and Correctional) \\ named after Professor T.Ponimanska, \\ Rivne State University for the Humanities, \\ Rivne, Ukraine \\ ORCID: 0000-0001-5986-264X \\ e-mail:Vrudenko2004@gmail.com
}

\begin{abstract}
In the article approach based on the isomorphic identity of an education and culture systems are offered. An idea consists in planning of different semantic forms of the culture in the process of studies and development of students. Education is presented in the context of culture and civilization. The cultural trends modeling of the higher education content is based on the isomorphic identity of education and culture. The main idea is to fill the content of higher education with cognitive, valued and regulatory forms of meaningful understanding of culture in the process of vocational training. The content of education and upbringing is differentiated in the context of culture and civilization. The target component of higher education is built in the culturological paradigm of the humanistic type (the paradigm of a person of culture), which determines the necessary and sufficient conditions for the formation of an integrated system of professional and personal qualities of a university graduate. The model represents the unity of the spiritual, moral and technological components of training. This reflects the objective need of a person, society and the state for
\end{abstract}


a high level of development of professionalism, competence and personal qualities of future specialists. The model of the content of higher education isomorphically reflects the basic didactic features and characteristics of the structure and functioning of the modern humanitarian cultural and educational system. The totality of conceptual principles is built on the basis of the dialectic of the unity of culturalogy and anthropology, revealed at the philosophical, general and private scientific level of representation. At the theoretical and normative levels of modeling the possibility of presenting the content of higher education with the help of the categories of "value" and "sense" as a means of integrating spiritual, social and technological components of culture into a holistic "subject reality" is laid down. The educational process is modeled as a kind of cultural act (event), based on a value hierarchy, as well as mechanisms for assimilating content in the form of value and sensies by transferring them by subjects to the level of personal meanings (cognitive, meaning, regulatory). Personal senses are the main generators in the structure of a holistic consciousness of the personality and at the same time universal structural elements of culture.

Keywords: culture, civilization, model, content, meaning, value, sense.

Стаття надійшла до редакиії 30.09.2019 p. 